\title{
Psychological Factors Involved in Banking, as Encountered in Two Novels
}

\author{
Sinan Çaya \\ Institute of Marine Administration and Sciences, Istanbul University, Turkey
}

Copyright $\subset 2016$ by authors, all rights reserved. Authors agree that this article remains permanently open access under the terms of the Creative Commons Attribution License 4.0 International License

\begin{abstract}
This article compares an American bank in an unknown state in the United States in 1970s with a French bank of $1850 \mathrm{~s}$ in Paris. Even though those monetary institutions are fictitious as given, one can indeed infer a lot of truth and realism behind the hidden transcripts. As presented in the involved literary works; the French bank depicted by Émile Zola and the American bank thought up by Arthur Hailey are, despite the differences in time and geography; very similar in their functions. The former is only more deeply embedded in the stock exchange while the latter is essentially dependent upon loans made possible thanks to depositors. A war of nerves and extreme stress underline the themes of both of those superb novels.
\end{abstract}

Keywords Bank, Banking, Money, Stock Exchange, Shares, Profit, Gain, Feelings

\section{Introduction: Two Banks, Different Dates and Countries}

The original version of this manuscript was a graduate term-paper (submitted to Assoc. Prof. Mahmut Tekçe), which the author (yours truly) developped in a hedonist attitude, with great pleasure! Unlike most other compulsary papers along the course of my graduate-years; this paper was far from being an obligation or drudgery merely aiming at the fulfilment of a requirement.

The work makes a comparison of a French bank with an Amercan one. Timing is wide apart between the two. Nevertheless; both are western countries and in both it is the capitalist economic system which prevails. Those two sheer criteria render the attempted comparison quite plausible, indeed.

I had run into the French work in a half-price bookstore, by chance. This coincidence spurred my memory and made me remember about the other book. I got to search the other book in other second-hand book dealers in Istanbul. And I eventually located it somewhere.No offence, on my part! One might as well go ahead and label all that work an opportunistic research, based on the serendipitious (accidental) discovery of the mentioned French novel..

Émile Zola's main character in the naturalistic novel L'Argent (money) [1], is Aristide Saccard, an incorrigible financier who had previously lost fortunes at the stock exchange. He is impressed by his engineer-neighbor Hamelin's projects about prospective construction activities with a Catholic-missionary purpose, in the Anatolian part of the Ottoman territory as far as to Jerusalem. Establishing passenger ship companies, exploiting mines near the Carmel Mountain, construction of railroads mines are among the foreseen developments. Seizing the chance of joining forces with this technical master mind, this time he intends to start again, but solely to accomplish gigantic gains for his part.

The two men get in league with other acquaintances of Saccard and set up the Universal Bank ${ }^{(1)}$ (Banque Universelle) whose directorate is now incumbent upon Saccard.

From the very beginning, he and his associates essentially buy their own stocks instead of exposing them to the public in entirety. They conceal this fishy, manipulative maneuver via a few dummy persons visible at the front scene.

In actuality, whatever the country in question happens to be, certain formal and indispensable steps are required by law in setting up a finance business:

[For instance] After the decision to offer the company to the general public, a stockbroker is needed for the process of flotation [or going public]. A prospectus must be drawn up. This document sets out the details of the company structure, the history of the business, full names and addresses of the directors, the profit end expansion projects audited by another firm of accountants. In the past some very dubious schemes have been foisted [concealed, hidden, covered up] on the general public with very little true information to back up extravagant claims. As a result people were misled and money lost [2].

Hamelin's sister displays that she read the statute-book (le Code) and distinguishes between obligations (where there is no game and a certain percentage goes to the lender) and actions (in the case of which the associated person runs the 
chance of winning and losing. She specifies that she prefers the former and not the latter of the two choices. Saccard reassures her successfully (Summarized from the original work in French, p. 141) [1].

Saccard is on bad terms with his influential brother, Cabinet member Rougon ${ }^{(2)}$, as well as the affluent Jewish ${ }^{(3)}$ stock market champion, Gundermann.

As for the bank imagined by Arthur Hailey [3]; it is placed in an unnamed mid-western American state in mid 1970s. The top man, a descendant of the founder, dies unexpectedly.

A competition ensues between the two possibly most appropriate candidates at the second highest level for the vacancy of the CEO. The first voting session at the board of trustees ends up in a stalemate, with a soon-following election of an aged interim figure, Jerome Patterton, for a period of roughly a year, before his inevitable retirement.

This development merely adds more fuel to the bitter rivalry among the two highly-placed candidates, Alex Vandervoort and Roscoe Heyward, both of whom are looking forward to the date a year ahead of them.

The former candidate's wife is mentally ill and shut in a private clinic. The man is sustaining a constant affair with a female lawyer and left-wing activist, Margot Bracken. He is a fairly liberal-minded man. The latter candidate is a conservative type of man and is happily married to a blue-blood elegant woman; whose family, nevertheless, had lost their wealth long ago. The couple relies on the husband's bank manager salary.

\section{The Greedy French Financer Starts His Fiscal Game in Paris (1864)}

Saccard needs to collect around himself men who arouse feelings of confidence in financial topics and who are not so meticulous regarding compliance with specified regulations. The bank is to attract capital and sustain (through speculative movements) the financing of the oriental projects of the enthusiastic engineer-friend in Constantinople (Istanbul) and other cities, including Jerusalem.

Madame Caroline; the white haired but young faced sister of the engineer; despite her initial hesitations regarding the dubious nature of the "offer" of the shares to public purchases, is attracted to the resolute man and assumes the role of governess of his household.

Broker Sabatani is recruited as the chief straw man much needed to cover up inappropriate happenings; while former academician, jobless Jantrou gratefully takes on the editorship of the commissioned propagandist-newspaper.

Meanwhile debt-collector Busch reveals to Madame Caroline the existence of the child-Victor, whom Saccard had begot by raping a young girl some years ago. La Méchain is the debt-collector's "aid-de-camp" and the big woman's frayed leather bag contains rolls of old receipts. In fact it is a hand-written paper among all the debris of paperwork promising money to the then-raped girl ${ }^{(4)}$, which helps the two cronies track the identity of Saccard, the unaware father.

(Saccard's older legitimate child Maxime is a widower living off the money inherited from his rich dead-wife. He keeps his relations with his greedy father at a minimum). On her own initiative, Caroline "buys" the child from the two clever cronies and places him in an orphanage-like work house.

In spring 1865 Saccard decides to double the bank's capital while already a good part of the former subscriptions are stored in the bank's own vault. The good optimistic news (aggravated by the bank's own printed news media) compels the upward course of the shares and flares the speculative hopes.

\section{The Initially Problem First Mercantile Undergoes Some Abrupt Changes (1975)}

Old Ben Rosselli calls for an urgent meeting and announces his terminal illness in a cold-blooded manner at a cocktail party!

Ben Rosselli has no heir, an only son had been killed in action in World War Two and a grandson in Vietnam (paraphrased from Hailey 1975:13) [3].

Thanks to his noble wife, the social networks of Heyward are highly-placed and quite rich. Honorable Harold Austin, a former Congressman and a present business man, is the first person whom he calls and informs about the turn of events (paraphrased from Hailey 1975:15-16) [3].

[While Roscoe Heyward indulges in telephone traffic], Alex Vandervoort weighs the probable consequences. Roscoe Heyward had been around in the bank longer and has a considerable following on the board; for all the talent and experience he himself has in possession (paraphrased from Hailey 1975:23) [3].

The board meets, none can force the balance. The board meets again only to choose the aged interim.

Meanwhile, in the main branch of the bank just next to the general directorate, headed by female director Edwina D'Orsey, a Hispanic female teller has a short of some thousand dollars on her cashbox. After Edwina's careful consideration of the problem with her ingenious insight, the female teller is eventually acquitted, following stressful cross-exams.

Instead, the senior bank teller Miles Eastin is pinpointed as the thief. He is also proven guilty of other deceits, namely stealing from "sleeping" accounts where no money movement had been observed for a long time.

The employee is convicted and sent to a federal prison. In the prison his knowledge about the history of money brings him some prestige after some awful experiences like being gang-raped in the showers. The Mafia row gets interested in his counterfeiting talents, also. Credit card manipulators are closely connected with those types. 
In fact, the bank is losing a lot of money due to credit card embezzlements. It is a big preoccupation for the studious chief of security to think up new measures against forgers continuously.

The chief of security is a black ex-police chief, a man of rigid principles ever since his days in official uniform. He had been offered the job by old Ben in person, after coming to clash with him in his relentless attitude towards the powerful CEO, regarding a traffic ticket, at the time.

In other ways, the bank's money security system comes to the attention of the reader with all its minute details. Each teller memorizes his combinations and confides them to nobody else, for instance. At many stages two employees co-work to open cashboxes, each constituting a security measure for the other.

At times, the Headquarters Audit Staff all of sudden may bust a branch of the bank at the closing hour, keep all employers inside for a matter of hours at that late time, and go through meticulous checks of all accounts and procedures.

\section{The French Financial Hero Scores Points in His Endeavor}

During the seven Weeks War between the Prussian and Austrian armies everybody expects a sinking of the shares on the stock exchange. Deputy Huret, one of the henchmen of Saccard and a member of his fiscal circle, brings a telegram negligently left over at the table of his boss, the minister-brother.

Informed about the imminent would-be peace treaty ${ }^{(5)}$, Saccard buys all the securities he can buy and wins an outstanding commercial victory. In his joy, he decides to double the bank's capital once more. The formerly stagnant shares of the bank register an immense leap again. Still an important number of the banks own shares are are kept for itself, an illegal procedure besides being a very risky procedure.

The bank's location is changed to a more spacious and luxurious building. One night Caroline discovers his man's infidelity towards her by the frivolous la baronne Sandorff, an eager speculator who also expects accessibility to secret stock exchange information through Saccard, the new champion of the stock exchange market.

In her unhappy mood Madame Caroline opens her heart to son-Maxime for some consolation. The young man mentions about his father's worship money, emphasizing his opinion that the man could sacrifice anybody for that purpose without blinking his eyes.

Intoxicated by the new waves of success and glory; Saccard gives up all measures of caution and keeps ballooning the shares amid fictitious subscriptions. He inspires confidence to all hesitant adherents merely by his apparent devotion to the bank's accomplishment as well as his immense and radiating personal charisma ${ }^{(6)}$.
It is crazy! But, great men of finance and wars! Aren't they usually mad men who come to capture the success? (Translated from the original work in French, p. 408) [1].

\section{The American Bank Diminishes Aid for Social Purposes}

Alex sometimes quarrels with his activist-girl friend. In the aftermath of a quarrel they usually make peace with mutual concessions from their previous positions and strength of former opinions:

[For instance], Alex bringgs to her some credit cards and they examine the advertising proofs printed on the cards. The catch-phrases seem to be all lies, affecting people's behavior and urging them to go into unnecessary debt. Alex is not so sure of his position at first and in a sense; he needs the blunt, open verdict of Margot. Indeed, she speaks her mind openly and he can't help recognising the truth in her words (paraphrased from Hailey 1975:23) [3].

On one occasion, the interim-CEO assembles the board for an important affair, a cutback on the loans for the Forum East, a project of housing for low income families. Alex expresses his opposition for the cut, earnestly defending the social role of a bank ${ }^{(7)}$. Roscoe, in favor of profitability rather than possible contributions to society, rigorously defends the cut and wins the argument with the implicit approval of the interim-man.

The poor households involved loose no time for retaliation. Organized by Margot, who stays behind the scenes for not calling to minds an association with Alex, long lines of poor people invade Edwina's main branch. (Margot happens to be a cousin of Edwina, so she has another close person affiliated to the bank. It is Edwina who had introduced the couple to each other at a party before).

The assembled people had previously been instructed to avoid all suggestions of violence. They are polite. They mean no harm. They just want to open small deposit accounts for their small "savings" and at the same time to "help out" the bank, which is obviously encountering difficulties. After all, a reduction in the support loans for the poor housing project had to be realized.

The organized lines of poor citizens (mostly blacks and Hispanics) keep the branch busy for the sake of those trivial accounts. The Press takes up the issue. Bad publicity begins to hurt the bank. The shares of the bank at the stock exchange are very slightly lowered; but even this infinitesimal reduction is a horrible development for the managers. The Board come together and renounces the cut decision. Victory is insured for the activists.

A newspaper article appears insinuating the friendship between the female lawyer and the prominent bank manager. Alex undergoes a difficult ordeal before the board because of this. He has a hard time proving his unawareness about the organized movement beforehand. 


\section{The Might-Game is in Full Swing in the French Capitol}

Gundermann, former champion of the stock exchange, an old man with digestion difficulties, who lives on milk despite his affluence, is unhappy about the ascent of Saccard. Saccard's feelings are only reciprocal. If he had his way, he would even pull off the milk money from that "dirty Jew"!

Gunderman sells some quantities of Universal shares in order to force the price down. He keeps losing money; but he is in possession of immense patience and perseverance.

Deputy Huret, witnessing the insistent cold attitude of the minister towards his brother, gets more suspicious about the sustainability of the high prices and secretly sells his own shares.

Attorney Delcambre surprises his lover, la baronne Sandorff, with Saccard ${ }^{(\mathbf{8})}$. He vows to avenge this man. Soon, he is promoted to the position of justice minister, a position giving him an extra edge.

La baronne Sandorff visits Gunderman, proposing to spy on Saccard. The Jewish business man is imperturbable like a piece of stone when it comes to keeping his head in front of an attractive female building up his masculinity with coquettish airs. He is not impressed at all. He only hints that maybe later some more solid information may open the door to a real alliance between her and himself.

Busch, the financial intermediary, usurer and debt-collector who wouldn't hesitate to act like a commercial-blackmailer if necessary ${ }^{(\mathbf{9})}$; considers the time ripe to squeeze money directly from Saccard, concerning the matter of the illegitimate child. He sends a letter to invite Saccard for an interview.

Saccard goes there with a double purpose. First he settles the smaller debt (two hundred francs) of newly-married-Jordan, his redactor in the newspaper, in order to prevent the seizure of the house furniture of his employee by the pressing opportunist (trans. \& paraphrased from the original work in French, p. 366) [1].

Next, the opportunist middleman comes to the big story as he conceives it: He reminds Saccard how he violated a 16-year-old girl some years ago and how he promised her so many banknotes by his hand-writing, which went unpaid. He produces the evidence. His confederate La Méchain is standing next by with her enormous infamous time-worn leather bag full of depreciated securities processed continuously for a good new chance to come up with. Saccard learns about the death of the girl and the existence of Victor and the reclaimed exorbitant expenses supposedly spent along the course of his growth in the awful slums of the city. But Saccard is too clever and too informed to be blackmailed. He replies that the child deserves the money as inheritance from his mother. As for the probable scandal of an illegitimate child, he solely notifies his interlocutors that he doesn't give a damn about this issue! The two cronies are like thunder-struck. After all, they must acknowledge, Saccard is not known as a person of moral considerations. Rather, is he not a chaser of skirts? (Translated \& summarized from the original work in French, pp. 367-370) [1].

Meanwhile the artificially overestimated values ${ }^{(10)}$ of Universal shares attract growing suspicions on the part of the rivals, above all Gunderman.

\section{A False Decision \& Bad Consequence for the American Bank}

To gain some extra points against his opponent Alex, Roscoe clings to the recently vaguely suggested idea of supplying loans to a big multi-national conglomerate. The sheer name of the conglomerate, SuNatCo ${ }^{(11)}$, seems bound to add more prestige to the bank.

His former Congressman friend acts as a go-between to quicken the project. The two men are invited by the multi-national giant's CEO, Big George, to a short excursion in Bahamas.

The conglomerate's luxurious airplane flies them. The catering facilities during the flight are incredible: female stewards in uniforms, exquisite food being served, possibilities for taking showers etc. The vice-president of America is also a guest on board. Roscoe is really impressed.

At the villa at Bahamas, Avril, the girl specially assigned to his service since the beginning of the excursion begins to circle around the devout (loyal to the Episcopalian Church) and dutiful Roscoe, trying to seduce him. The second night she escorts him to his room again, promising to be available at any time for any service whatsoever, again.

"He lay awake for nearly an hour...Despite his best intentions, the focus of his thoughts was Avril. He tried to move his thoughts away - to banking affairs, to the supranational loan, to the [additional] directorship which Big George had promised. He paced again, and then returned to the window, standing there. Twice he made a move towards the bedside table with its intercom. Twice, resolve and sternness turned him back. The third time he did not turn back. Grasping the instrument in his hand, he groaned - a mixture of anguish, self-reproach, heady excitement, heavenly anticipation. Decisively and firmly, he pressed button number seven" (Hailey 1975: 232-233) [3].

Later, it will turn out that the multi-national conglomerate is in bad shape and is floating above water by paying debts with other debts and concealing their real difficulties. The CEO, Big George is only a crook, swindling all he can and preparing to escape to Costa Rica, a country which does not repatriates fugitives.

Once the huge loan is granted, the so-called giant will go default and almost ruin the bank. Roscoe will commit suicide, in guilty conscience.

The connection of the bank with the collapsed company will bring bad publicity and a bank run, which will only be contained thanks to the excellent leadership of Alex. The 
hero will urgently be proclaimed as the new president of the now weakened bank.

\section{Climax in the French Capitol!}

La baronne Sandorff, who had searched Saccard's pockets and found evidence of his inside trading, makes a second visit to Gundermann. The cold reception of the aged Jewish business man disappoints her. The man conceals his delight in the new information. When the woman inquires about formerly hinted bright promises; he simply advises the seductive young woman to stop gambling on the stock exchange.

After dispelling her he immediately prepares his new strategy of attack with his own close circle. The new attack of selling Universal's shares is more determined than ever. The defence sags this time. The treasury of the bank empties. It is not possible to sustain the ballooned prices of the shares any more.

Introducing-brokers supposedly working for Saccard begin to act like schemers furtively towards the last moments, selling their own shares, let alone buying for the Universal Bank. (The fidel one, Mazaud, will commit suicide by shooting himself. Chief traitor Sabatani and his associate Fayeux will end up rich and quicky vanish from the scene).

But above all; Daigremont, Saccard's richest partner, once he flairs the danger, openly chooses to betray his friend. He shouts at his own henchman:

-Defeat, defeat mon cher! I cannot stay more in a house which is about to collapse soon. This would be useless heroism! Do not ever buy any more. Do the opposite! Sell! Sell the shares! All of them! (Translated from the original work in French, p. 410) [1].

Alas! Saccard, the commander-in-chief ${ }^{(12)}$, was especially dependant upon his most powerful general for the last surprise attack! This was to be a surrounding operation by the fresh cavalry force: An urgent buying of Universal shares by the introducing brokers of Daigremont at the very critical and decisive moment and at the second most important front: The Bourse of Lyon ${ }^{\left({ }^{(3)}\right.}$. But this eagerly-waited invaluable aid never came.

$\mathrm{He}$ and the engineer get sentenced to five years. Caroline is first full of hatred against Saccard. She keeps visiting her beloved brother, omitting another visit to Saccard's cell until finally the brother asks him to do it.

She witnesses no remorse in that resolute man. He is asserting that he did what any bank director does but in a larger scale and as a strong man would do. He is considering himself just a scape goat (translated and summarized from the French work, p. 486) [1].

Saccard affirms that if Napoleon at Waterloo had had a hundred thousand more men to send to the line of death he would have been victorious. In a similar manner, if he had had a few hundred million bucks more, he would have ended up as the master of the world (translated and summarized from the Frech work, p. 488).
The minister-brother commutes the sentences to exile abroad.

\section{Conclusions}

Although the two banks are far apart as far as the countries and dates go; they have a lot in common. After all, a bank is a very important institution of a capitalist society as the manager of hot money, the flowing blood of real economy. Stock-exchange resembles a bank a lot, in the sense that it also is a financial institution. Attempting a comparison between two such entities could only be logical and practical. Indeed; they do display similar working principles and employee-mentalities as well as a prominent greed for gain in the background (the main psychological factor) and parallel risks of failure and immense losses!

\section{Notes}

1. [In real history too] the first French bank in the form of an anonymous company was established by the French government in 1852 at the time of Napoleon the Third. Société Génerale de Crédit Mobilier was a manifest indicator of the trend towards the finance capitalism. The bank combined the corporation idea with the deposit banking practice of mid-Europe and became a role model for commercial banks providing finance for entrepreneurial pushes (Allen 2003:26-27 as re-converted into English from the translation work of Tekçe, in Turkish) [4].

2. Not proud of his uncontrollable financier-brother, the powerful politician had even forced him to change his last name, previously. Thus the name became Saccard.

3. Unlike his novel's hero, however, author Zola himself is known to have no hard feelings against Jews, as clearly indicated in the Dreyfus issue. This point was in fact contained as a footnote by one of the translators of the original work.

4. Another rape story to be abused by the two cronies takes place towards the end of the novel. Defunct Earl of Beau Villiers raped a girl; wrote a bill promising to pay her ten thousand francs when she attains maturity. The paper ends up in that notorious leather bag and is identified (p. 38). The two vultures delay the blackmail until the widow and her daughter lose all their wealth by buying shares of the Universal Bank. Meanwhile the daughter is attacked and violated by Saccard's illegitimate son, Victor, at the orphanage, where she does voluntary work. The vultures confront the unhappy countess at the poorhouse and threaten a shameful publicity. The girl in question, Léonie, now a desolate senior prostitute, is also confronted with the old princess. The poor daughter, in her sick bed hears all the truth about his honorable father, the count. The jewelry of the mother, the last vestige of their former wealth goes to the blackmailers, just to buy their silence.

5. The Paris stock Exchange is very sensitive to external 
developments. On another occasion bad news (mauvais bruits) is mentioned about the Suez Canal works. Jobber Moser says to his colleagues in a low voice that the British want to prevent the digging activities in Egypt and a threat of war is imminent (translated and summarized from the French work; 1891, 1994: 15) [1].

The excavation took about ten years, ending in 1869. It involved forced labor. The French accomplished the work, which compelled the rivalry of the British Empire. (As given on p. 69 of the original work in French) [1], engineer Hamelin and his sister teacher-Caroline had witnessed the first picks digging at the canal soil. (As given on p. 95) [1] they even met the Grand Vizier, Fuad Pacha in Constantinople. So the interest of the engineer for construction-works in Near East is well-founded.

6. The word "charisma" which we employ here is very explanatory even though chronologically it is retrospective. The word was to be coined by Sociologist Max Weber, born about a quarter of a century after the death of Émile Zola.

7. Indeed, a bank cannot be regarded purely as a profit organization. The social responsibilities are gaining more and more ground in modern times: All public receipts and expenses represent economic and social dimensions because all either directly or by impact, act upon the economic lives and social situations of countries. Formerly those economic and social aspects of public finance were considered of a secondary nature with respect to political ones. But today they are very important and they occupy a place in Fiscal Economics (Trotobas 1960: 46) [5].

8. Parisian high society is known to shake with scandalous love affairs at the times. Other writers like Gustave Flaubert (the author of Madame Bovary) and prolific British historical novelist Barbara Cartland also depict those forbidden acts of love in their works. Naturalist-Zola; however; usually depicts related scenes in a matter-of-fact or even ugly manner, instead of relying on a more romantic approach. Broker Sabatani, for instance, is a topic of curiosity and a cause of whispers among certain womenfolk, due to his length phallic member. Also; jokes circulate whereby paper-editor Jantrou is said to make tattoos on the most in time parts of women advising to buy the shares of the Universal Bank.

9. For all his unscrupulous ways as a bottom-feeder, Busch is a marvelous senior brother. He takes care of his young intellectual brother, suffering from tuberculosis under his protection and cares for the health of the delicate youth. Brother Sigismond is an idealist committed to the new ideas of Karl Marx. He believes in the eventual abolishment of the dirty Money system. Upon Saccard's arrival the big brother is absent. Until he appears Sigismond engages into a philosophical and friendly conversation with Saccard.

10. Indeed; sometimes on a stock exchange the struggle between two opposing parties might as well be regarded as a sheer duel or match reduced to an endurance test, when it comes to forcing prices artificially by continual buying or selling shares. Author Erdinç (2006: 260-261) [6] narrates in
Turkish the exceptional success of the Central Bank of Hong Kong in 1997-1998:

[The international "Financial terrorists" who are experts in inducing crisis in a country and making a profit of the misfortune; resorted to the same notorious technique in Hong Kong. By short selling methods thanks to their immense hedge funds, they were sure to make huge profits once again] However; Hong Kong happened to possess much more money at hand than expected. The Central Bank started fighting like a lion, realizing an example perhaps without precedent in the modern financial history by buying shares from the stock exchange. In this manner, the prices of the shares short sold by the enemy were rapidly climbing and causing damage to the enemy. The enemy paid extra rents to the owners of the short sold shares, gaining further waiting time by renewing terms. But the government would not let things go. It firmly stayed in the cycle. Eventually it was the enemy who had to retreat.

Zola (p. 460) [1] uses a similar phrase, financial banditry. La princesse d'Orviedo, a mystical widow, dispenses her defunct husband's entire inheritance on virtuous deeds (charity, orphanages etc.) once she learns about the origin of that wealth: Cursed money, collected in the mud and blood of financial banditry.

11. Some critiques are known to connect this imaginary firm to ITT (in real life. The big company was accused of having its finger in the preparation of the downfall of Salvador Allende from power in Chile in 1973.

The first example of a multi-national conglomerate is ITT. In late 1960s the immense economic and political power of such entities began to cause anxiety in many circles. Secretariat of Justice [in the American Presidential system it is the equivalent of the Ministry of Justice elsewhere] had to sue the conglomerate, regarding violation of anti-trust laws. Before the decision of appeal ITT agreed to give up some of the appropriated companies. Today in the U.S. a firm has to get the approval of the Secretariat of Justice before incorporating another firm to its own structure (Allen 2003: 37 as re-translated back into English from the work of Tekçe in Turkish) [4].

12. On many occasions Saccard is compared to an army marshal by his creator, the author-Zola. Saccard leads a war of nerves simultaneously with a financial war. Many times Zola uses money being lost on the stock exchange as a metaphor for soldiers being decimated at the battle front. Saccard is worth admiring for his foolish courage until the very end. He never reveals a weakness to his introducing brokers. He keeps giving the orders, his face impassible, as always. Indeed, a good gambler's face should be unrevealing like a mask. In English, as a matter of fact, they use famous idiom "poker face".

13. Lyon has been another focal point in French finance 
matters: Lyon was the financial center of France in the sixteenth century. In 1570 s the city suffered a blow due to the fiscal bankruptcy of the Spanish Kingdom [with which it was intricately involved] and lost the first place to Paris (Allen 2003: 37 as re-converted into English from the translation work of Tekçe, in Turkish) [4].

\section{SUPPLEMENT: Some Visual Material}

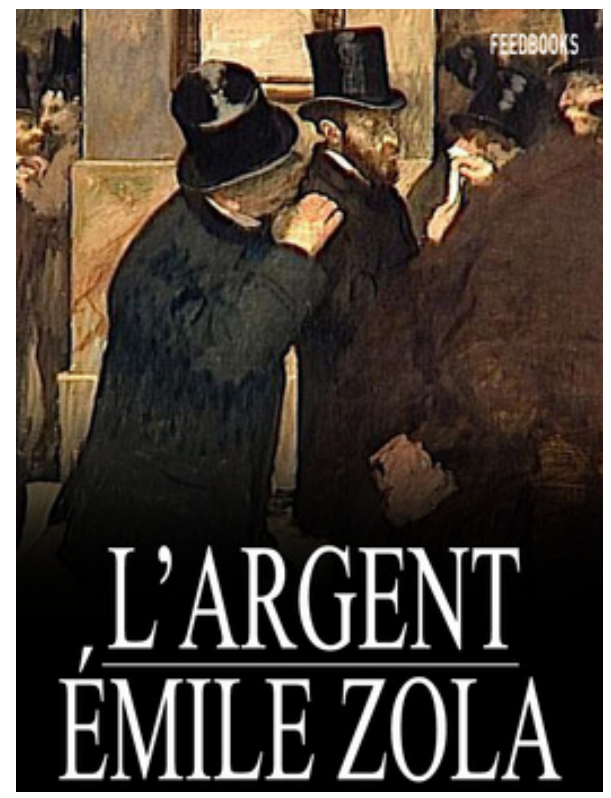

Figure 1. Cover of one of the various editions of the famous novel by Zola (internet)

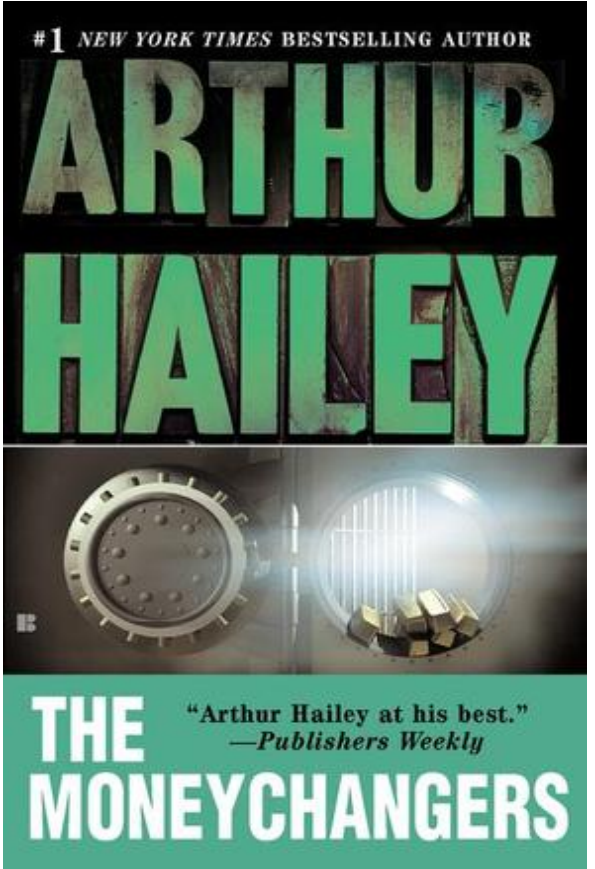

Figure 2. Cover of one of the various editions of the famous novel by Hailey (internet)

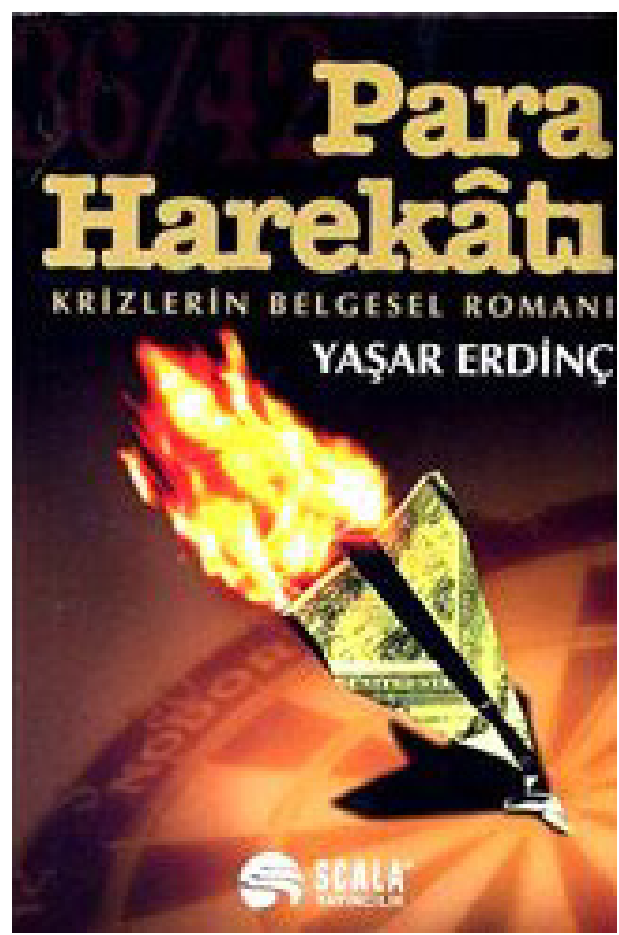

Figure 3. Cover of the didactic financial novel in Turkish (internet)

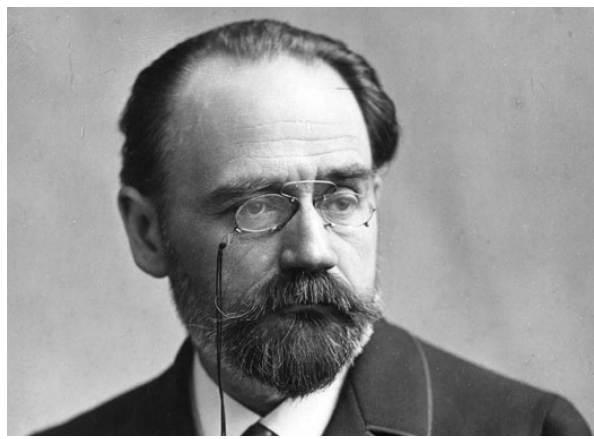

Figure 4. French author Émile Zola (1840-1902) (internet)

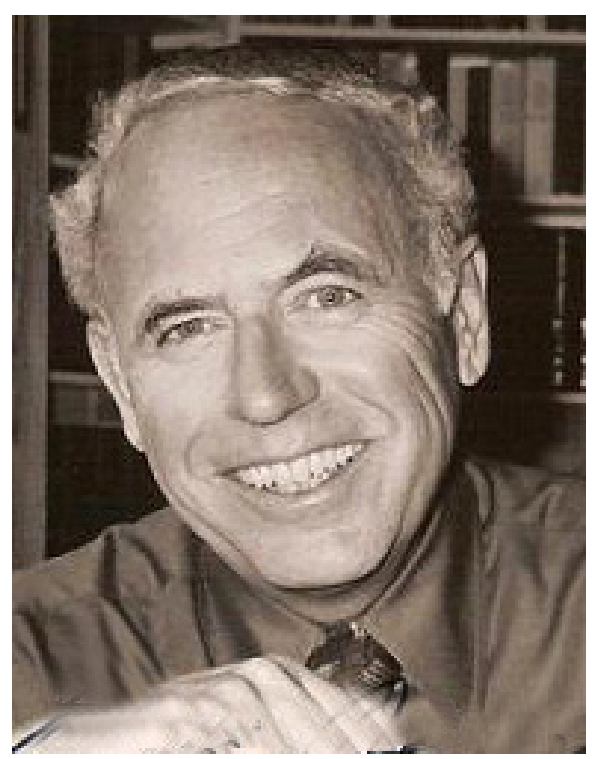

Figure 5. British-born American Author Arthur Hailey (1840-1902) (internet) 


\section{REFERENCES}

[1] ZOLA, Émile (1891, 1994). L'Argent, texte intégral, Docelles: Éditions Carrefour.

[2] WHITTAKER, Noel (1987). Making Money Made Simple, Brisbane, Queensland, Australia: Boolarong Publications.

[3] HAILEY, Arthur (1975). The Moneychangers, London \& Sydney: Pan Books.

[4] ALLEN, Larry (Mart 2003). Keseden Bankaya, Tezgâhtan Borsaya: Küresel Finans Sisteminin Öyküsü [The Global Financial System 1750-2000], (translated into Turkish by Tekçe, Mahmut), Beyoğlu-İstanbul: Kitap Yayınevi.

[5] TROTABAS, Louis (1960). Institutions Financières, $3^{\mathrm{e}}$ édition, Paris: Librairie Dalloz.

[6] ERDİNÇ, Yaşar (Kasım 2006). Para Harekâtı: Krizlerin Belgesel Romanı [Fiscal Operation: The Documentary Novel of Crises], Beyoğlu-İstanbul: Scala Yayıncılık. 